\title{
Questioning the public policies for the adolescent girls of Malda district: A Sociological Study
}

\author{
Dr. Srabanti Choudhuri \\ Assistant Professor in Sociology, School of Social Sciences, Netaji Subhas Open University, West Bengal.
}

\begin{abstract}
The paper seeks to study the impact of the public policies on the education and marriage among the young girls in the Malda district of West Bengal. That many policies are in vogue in the state are quite well known, but how far they have fared in coordinating the adolescent girls in the right order is questionable. The paper will try to understand how far the public policies have been able to issue the burning issues of literacy and early marriage among the adolescents in the Malda district of West Bengal.
\end{abstract}

Keywords: Policies, education, marriage,adolescents,rural.

\section{Introduction}

The work intends to study the present status of women, education and marriage among the young women of Malda district in West Bengal. Malda district has been selected for its social and economic backwardness. It has almost one million plus population (2006, GOI) and it is relatively more economically distressed according to the human development index (2004, GWB). The district has drooping sex ratio, accelerating rate of child marriages and frequent incidences of women trafficking across the border. For a state so vulnerable for its women inhabitants, the issues for gender equality and education seemed unaddressed. The objective of this paper is to investigate the present status of the young women in the district especially in the area of social empowerment and education and to study the impact of public policies on women.

In the present socio-economic context, can the government schemes ensure empowerment across different classes of adolescent girls in Malda district? The researcher wants to see whether the state policy has taken adequate initiatives for social empowerment among the young and the adolescent women such as:

- Whether it provides easy and equal access to and free education for women and girls.

- Whether early marriage has been stopped?

- Whether school dropout could be arrested?

Primary data has been collected from all these four villages. Data has been collected from young and adolescent women (from age range of 15-19 years) across different socio-religious groups like Hindu Scheduled Castes, Muslim OBC groups and Scheduled Tribes. We went to both schools and households to collect data. Data will also be collected from Census of India, District level Household and Facility Survey, Human Development Report 2004 District HDI, Education, National Health Mission Five Yearly Report, National Family Health Survey ,Population Foundation of India, Planning Commission, All-India Educational Survey, NCERT 1978, District Information System for Education (DISE) ,Paschim Banga Sarva Siksha Abhiyan and Malda Human Development Report.

\section{Overview of the Study Area - A Brief History of the District}

Malda district was formed with some parts of the erstwhile districts of Dinajpur and Purnea way back in 1813. Then onwards Malda shuttled from one division to another, starting from Rajshahi division till 1876, 
then Bhagalpur division till 1905, and then again in the Bhagalpur division from 1905 onwards. It was during partition that we find five districts to the north of Malda, viz. Shibganj, Nakchol, Gomastabpur, Nababganj, Bholahat which all went on to become parts of East Pakistan afterwards. After partition, Malda went on to contain South Dinajpur and Rajshahi of Bangladesh on her east. On her north is North Dinajpur and Bihar's Purnea district. On her north east is the Ganga and Padma River. The great river Mahanadi that runs across the district, divides the district into two halves in the east and west (Shom: 2006). The eastern half of Malda District is located $347 \mathrm{kms}$ north of Kolkata. The district has three most striking physiographic divisions. The Mahananda river cuts across the district in north and south giving the district an idiosyncratic physiological flavor. The eastern side of the Mahananda river is known as "Barind" and it is produced from the older alluvial and red clay soil. It is a comparatively high,undulating region with reddish and yellowish clay soils. Rice is the predominant crops grown in such soil briefly followed by wheat, mustard, pulses which are grown aplenty in Bamongola,Habibpur and Gazole blocks in Malda (Choudhuri:2019). It therefore is quite clear that the mainstream of the Mahananda abandoned its original course, and gradually flowed through the subsidiary channels down to the bed of the Nagore River. Not many speak of the Nagore river locally now. Now let us see the central programmes in vogue for the adolescent girls not just in Malda but in the country as a whole.

\section{Empowerment, Adolescent Girls and the Central Programmes}

The Ministry of Women and Child Development is implementing various schemes/programmes for empowerment of women and development of children across the country. The details of those schemes for Women empowerment are as followed:

- Pradhan Mantri Matru Vandana Yojana (PMMVY), \{erstwhile Maternity Benefit Programme\} has been contributing towards better enabling environment by providing cash incentives for improved health and nutrition to pregnant and nursing mothers. Scheme for Adolescent Girls aims at girls in the age group 11-18, to empower and improve their social status through nutrition, life skills, home skills and vocational training Pradhan Mantri Mahila Shakti Kendra scheme, promote community participation through involvement of Student Volunteers for empowerment of rural women.

- National Creche Scheme to provide day care facilities to children of age group of 6 months to 6 years of working women who are employed.

- Rastriya Mahila Kosh (RMK) to provide micro-credit to poor women for various livelihood support and income generating activities at concessional terms in a client-friendly procedure to bring about their socio-economic development.

\section{Impact of the State Programmes: The Multiple Dimensions}

Several state schemes are in vogue, notable amongst them are the Swasthi sathi, Kanyashree, Rupasrhree, Khadyasathi, Shikhashree, Tapasili bandhu, Jai johar, Manabik, 100 day's work, Aikyashree and some newly launched schemes are the Lakshmi Bhandar, Student Card, Krishak bandhu, Bina mulye samajik suraksha (updation of pass books) etc. of these, I concentrated particularly on Kanyashree.

\section{Beti Bachao Beti Parao: Its relevance in Bengal}

The Government announced Beti Bachao Beti Padhao programme to address the issue of decline in CSR through a mass campaign \& multi-sectoral action plan in 100 gender critical districts across the country. Prime Minister Shri Narendra Modi accorded top most priority to this issue by himself launching the Beti Bachao Beti Padhao campaign from Panipat district in Haryana on 22nd January, 2015. With a mission to increase awareness about the program specially in rural India, a special awareness campaign was launched by the Directorate of Field Publicity, Ministry of Information and Broadcasting, Government of India in February- March 2015 in collaboration with the Ministry of Women \& Child Development.

\section{Results and Discussion: Case Studies}

Students of Garadhul School were picked up for case studies. The first group comprised of the following girls: 


\section{Manika Sarkar-class XI (Mobile:8670995886)}

lives in Nangrashimal village of Chak nagar Gram Panchayat in Gazol block of Malda district. Manika's family lives in a mud house. Her father is a farmer owning around one and a half bigha of land for cultivation. Their house is built on 10 kathas of land whereas the rest of land is left for farming. They usually cultivate rice and mustard but come the monsoon season, the land is left inundated making it difficult to cultivate mustard. They are left with no other option but to cultivate rice as their only staple crop. Their main source of drinking water is tube-well located nearby. Manika lives with her parents and her brother who works for a living in Bangalore now. Interestingly, Manika when asked about her family forgets to mention her two sisters, who being married off to near-by villages do not stay with them. On further enquiry, we come to know that her sisters who were drop-outs were married off at a very tender age of 12-13. On prodding, her mother insists that with with her daughters being very indifferent and insipid towards studies, she had no option but to marry them off. She argues that with dull brains, what was the use of dragging off with academics, knowing there is very little future. Situations haven't changed even now for her much now for she insists, with dowry demands on the rise, K2 could be utilised for purposes for marriage. Even Manisha herself dis not show much keenness to continue with her studies for she felt it is upto her parents to decide she would continue with her further studies or not. Her mother was sceptical about the prospects of higher education and the relative chances to getting employed for she be;lieved very strongly that employment is largely coveted these days and sought in exchange of good shocks of money. For a poor family like hers with minimum assets it was a wild dream to see her daughter working and fetching a regular income for the family.

\section{Purnima Biswas-class XI (Mobile:8695450052)}

Purnima Biswas stays at Krishnanagar village of Chaknagar Gram Panchayat in Gazole. She stays with her parents and a brother who reads in class IX in the same school. They live in a semi kancha house because a part of their house is getting plaster. Though they have a tap nearby, it is difficult to use the water because of the preponderance of iron, making it difficult to drink. Drinking water can be accessed from sources that are around a kilometer from the house. The village has only one marshall to accrue water and therefore the problem subsists. The family takes bath in the Tangon river that flows in the village. Rivers remain a very distinctive character of Malda district. Several rivers drain the district, noted amongst them are Mahananda, Kalindi, Purnabhaba, Tangon, Bhagirothi, Fulhara, Behula and Pagla. Tangon remains one of the important rivers of Malda (Ghosh: 1950) and serves various purposes when it flows in this Krishnanagar village in Gazole. The river originates in Himalaya and merges with the river Mahanadi near Muchiya. The silted sediments of the river banks make it difficult to tread the roads. Tangon River in the monsoons is an altogether tedious affair. Of course Purnima and her parents do not lament for they are used to reconciling with this muddy thoroughfare for a long time. However, even if the water is used for bathing, the same cannot be consumed.

Purnima's father Nepal Biswas rues that in absence of only one Marshall, many householders take recourse to untreated tube well waters for drinking which end up upsetting their stomachs. Biswas himself after suffering from bouts of stomach disorders had to rush to the doctor along with his son, only to be advised not to administer such water any more for drinking. From then onwards, Purnima travels about half a kilometre every day to fetch water from the marshals with befitted filters to fetch drinking water for the house. The house has mud bathrooms and Biswas himself works as mason constructing bathrooms for the households in the villages. Biswas claims that most of the house has bathrooms of their own which have been constructed without any government aid but ruse that hoax calls for giving grants in the name of building latrines and sanitary pits run riot in the village. He says, just a few months ago, a group insisted that they be given an amount of Rs. 3oo for building bathrooms, to which the villagers obliged. To their utter dismay, athe grants never came and even the money they had deposited was never returned back to them. Such scams and chit-funds rule roost in the villages, but Biswas argues the poor villagers often give in to such traps without having the capacities to estimate the dicy outcomes. But not all is bad with the village, for they are getting new roads and mud silted roads are gradually giving way to concrete ones. However, 
Krishnanagar still does not have all-encompassing roads for the village, for the village has roads only till Modhyopara Kali Mandir and the areas beyond still have no roads.

Biswas though is happy to own a rice mill for himself where he pounds dried rice and mustard to get rice and oil for his subsistence. He however, does not have to deploy any manf from outside, for his family itself is engaged in drying and cleaning the stocks of paddy and mustards which they cultivate in their own house. Biswas is happy that with his supplementary sources of income, he manages to take care of his family. Owning some plots of land along with having a rice mill as well as acting as a mason, building bathrooms for the village, have quite helped him. The government schemes for improving the lot of the girls have changed, he believes but not much has changed though, he gives an afterthought. The dowry demands in the villages soaring high, the parents find it difficult to manage matches for their daughters. Getting a humble groom like him, owning a modest amount of plots and assets, can be as costly as 1.5 to 2 lakhs whereas going for a groom with a stable government service, preferably a school teacher, can be as pocket-pinching as 3-4 lakhs. Biswas points out to such a match fixed near his house where the son works in a school in the next block of Bamongola. The marriage was negotiated with a hefty sum and a proclamation that apart from the cash, the bride's family must decorate the newly built groom's house. It was a dual burden for the bride for not only did they have to fund their own marriage ceremonies but also give enough money to the grooms to aid their reception ceremonies as well. Poor parents go to any extreme to see their daughters happily married away, even if that hurls them to the disastrous dens of indebtedness and pauperization. Knyasree nevertheless have somewhat helped the girls continue with their schools, though often girls are married off early and by eighteen years they end up getting impregnated.

\section{Results and Discussions}

State policies, however doles, it may deliver will not go the long way in ameliorating the conditions of the women. Unless, parents become conscious of the rights of their daughters and give them the soft cushion, nothing shall really work. States before allotting doles for the poor families, must monitor, how much of it had been used for the purported causes. Then only the next round of doles will be given. Grass root organizations and advocacy groups must work side by side to make the policies work. Otherwise the funds accrued from the policies will be misused. For every state schools, colleges and universities, field work must be made a compulsory addendum. Otherwise states, alone cannot do anything.

\section{Conclusion}

Public policies funded by the Centre often remain out of the bound in the state. Policies like Beti Bachaon, Beti Praon are often not that popular in the state, mostly because od other flagship programmes like Kanyasree in the state. Besides, central programme, as stated above is more of a campaign and awareness drive and less of a programme per se. therefore, they were outdone by the state programmes. State initiatives like Kanyasree or Oikyosree are fund transfer programmes which easily stole the hearts of the young populace. As we had shown, the policies could not cut across the caste, class and ethnic barriers of the state in the villages and lead to overall empowerment of the girls, nevertheless it was judiciously used by certain slices of the society. One drawback definitely was that the lower sections of the populace still could not fully use this policy either for giving adequate education to its girls, nor could it address the early marriage pro0blem. Still, we can conclude that the policy was used to an extent by the marginal population, and it is miles to go before the state programmes bring smiles to our young girls.

\section{Acknowledgement}

I acknowledge the full support provided me by the ICSSR IMPRESS Project for awarding me this project and for thoroughly supporting me not just through the full-fledged financial aid but through all other multiple kinds of assistances, as and when required. I will remain grateful to the ICSSR and to the IMPRESS Team for ever.

\section{References}

1. Bajpai, Peeyush, et al. Social and Economic Profile of India. Social Science, 2006. 
2. Catalano, Amy J. A Global History of Child Death: Mortality, Burial, and Parental Attitudes.

3. Peter Lang Inc., International Academic Publishers, 2015.

4. Mathur, Kanchan. Countering Gender Violence: Initiatives towards Collective Action in Rajasthan. Sage, 2004.

5. Govinda, R., and Poornima M. India's Social Sector and SDGs: Problems and Prospects. Routledge, 2020.

6. Nanda, Bijayalaxmi. Sex-Selective Abortion and the State: Policies, Laws and Institutions in India. Shakti Books, An Imprint of Har-Anand Publications Pvt Ltd., 2018.

7. Desmond, Matthew (2016) Evicted, Penguin Books, USA.

8. Shah, Alpa, (2018), Night March: A Journey into India's Naxal Heartlands, Harper Collins Publisher, Noida.

9. Shom, Shushmita. 2006. Maldaha Jelar Itihaash Chorcha. Deepali Publishers.

10. Choudhuri, Kamal. 2019. Maldahar Itihaash. Deys Publishing.

11. Ghosh, Shailendra Kumar. 1357 (1950). Gour Kahini. D.M Library. Cornwallis Street. Kolkata. https://archive.org/details/in.ernet.dli.2015.356189/page/n5/mode/2up 